\title{
Pengukuran Refleksi Akustik Bola Sphere Menggunakan Instrumen Quantified Fish Finder
}

\author{
1Steven Solikin, ${ }^{2 H e n r y ~ M . ~ M a n i k *) ~}$ \\ 1Program Studi Teknologi Kelautan Program Pascasarjana IPB \\ 2Departemen IImu dan Teknologi Kelautan FPIK IPB Kampus IPB Dramaga Bogor \\ Coresponding author: henrymanik@ipb.ac.id*)
}

\begin{abstract}
Abstrak
Pengukuran nilai echo akustik dari ikan merupakan metode yang penting dalam pendugaan stok ikan. Data estimasi stok ikan yang tepat atau presisi dapat diperoleh dari akurasi instrumen akustik yang sudah dikalibrasi. Salah satu metode untuk mengkalibrasi instrumen akustik adalah dengan mengukur nilai echo dari sebuah target standar, yaitu bola sphere. Tingkat akurasi dari instrumen sonar yang dikalibrasi sangat tergantung pada karakteristik akustik dari target (bola sphere). Pengkalibrasian menggunakan objek bola sphere ini dilakukan pada instrumen akustik CruzPro PcFF88. Bola sphere yang terbuat dari material tungsten carbide dengan ukuran diameter $3 \mathrm{~cm}$ diletakkan pada jarak $1 \mathrm{~m}$ di bawah transducer CruzPro menggunakan frekuensi $200 \mathrm{kHz}$. Hasil yang didapatkan berdasarkan pengukuran langsung menunjukkan bahwa nilai target strength dari bola sphere tersebut adalah sebesar -42.5 $\mathrm{dB}$, sedangkan secara empiris nilai target strength bola sphere tersebut adalah sebesar $-46 \mathrm{~dB}$.

Kata Kunci: akustik; bola sphere; CruzPro PcFF88
\end{abstract}

\section{Pendahuluan}

Quantified Echo Sounder (QES) sangat banyak digunakan dalam survei akustik untuk mengestimasi stok ikan. Untuk mendapatkan hasil estimasi yang baik, diperlukan kalibrasi terhadap instrumen yang digunakan.

Pada sekitar tahun 1980-an, Foote ${ }^{[1]}$ bersama peneliti lain mengembangkan metode kalibrasi menggunakan bola sphere standar (metode kalibrasi sphere). Pada metode ini dilakukan pengamatan pada nilai echo dari sphere tersebut, pengukuran amplitudo, dan mengubahnya menjadi nillai target strength (TS) dari sphere tersebut.

Menurut Foote et. al[2], untuk mengkalibrasi suatu instrumen dengan menggunakan bola sphere ada tiga metode perhitungan yang dapat digunakan, yaitu: (1) sensitivitas on-axis dari keseluruhan echo-sounding dan sistem yang terintegrasi, (2) fungsi time-varied-gain (TVG) dari penerima (receiver), dan (3) sudut bim dari transducer. Perhitungan komponen elektrik dari komponen sistem juga dapat termasuk dalam faktor kalibrasi.
Metode kalibrasi tersebut dicoba untuk diujikan pada fish finder CruzPro PcFF88 yang memiliki spesifikasi seperti yang ditunjukkan pada Tabel 1. Gelombang suara yang ditransmit dari transducer CruzPro menjalar pada kolom air lalu mengenai target (bola sphere) dan kemudian gelombang suara akan kembali diterima oleh receiver transducer. Gelombang suara yang kembali tersebut dinamakan echo.

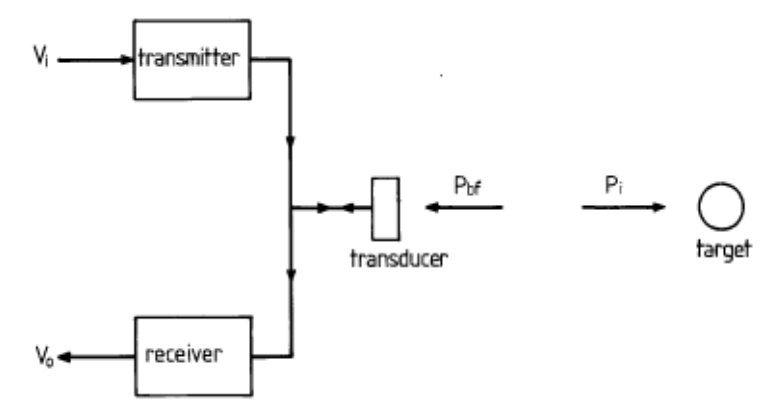

Gambar1 blok diagram pengukuran refleksi bola sphere

Tabel 1 Spesifikasi CruzPro Fish Finder PCF8850

\begin{tabular}{|l|l|}
\hline Parameter & Nilai \\
\hline Frekuensi $(\mathrm{kHz})$ & 200 \\
\hline Transmitted Power (Watt) & 320 \\
\hline Near Field $(\mathrm{m})$ & 0.38 \\
\hline Kecepatan Suara $(\mathrm{m} / \mathrm{s})$ & 1516 \\
\hline Durasi Pulsa $(\mathrm{ms})$ & 0.4 \\
\hline Ping Rate $(\mathrm{s})$ & 0.334 \\
\hline Amplifier Gain $(\mathrm{dB})$ & -20.83 \\
\hline
\end{tabular}

Menurut Sawada dan Furusawa[3], metode integrasi echo dari bola sphere memiliki keunggulan dalam tingkat presisi dan seharusnya metode ini lebih banyak digunakan dalam teknik pengkalibrasian. Perhitungan kalibrasi dengan cara eksperimen nantinya akan dibandingkan dengan perhitungan teoritis. Kami membandingkan hasil kami dengan penelitian yang dilakukan oleh MacLennan ${ }^{[4]}$. Menurutnya, nilai TS dari sebuah bola sphere sangat tergantung pada frekuensi instrumen, diameter, dan massa jenis dari bola sphere tersebut. Namun, nilai TS juga sangat tergantung pada kecepatan suara yang merambat di air dan pada bola sphere tersebut, 
dimana faktor kecepatan suara tersebut sangatlah sulit untuk dihitung.

\section{Metode}

Kami mencoba melakukan metode kalibrasi bola sphere dan integrasi echo pada fish finder CruzPro PcFF88 di sebuah water tank yang berisi air tawar dengan kedalaman maksimal $2.5 \mathrm{~m}$. Frekuensi yang digunakan sebesar $200 \mathrm{kHz}$ dengan pengukuran TS.

Bola sphere yang terbuat dari material tungsten carbide dengan diameter $35 \mathrm{~mm}$ diletakkan sejauh $1 \mathrm{~m}$ dari permukaan transducer, sedangkan permukaan transducer diletakkan sejauh $70 \mathrm{~cm}$ dari permukaan air.

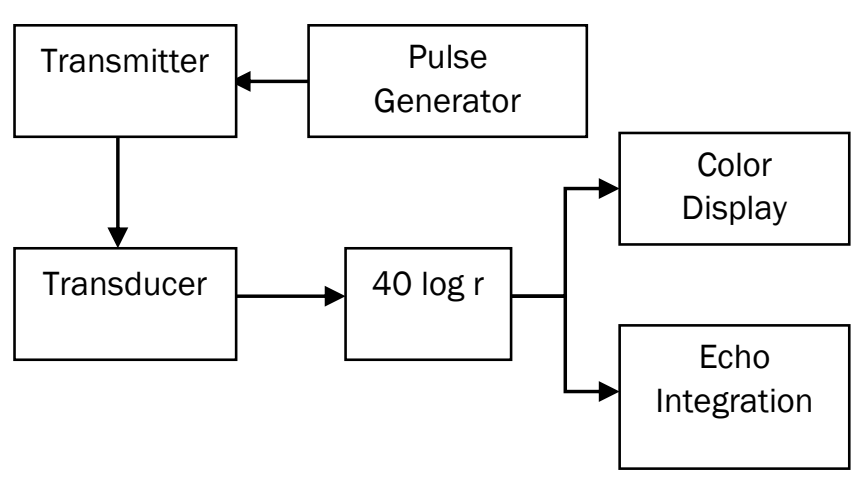

Gambar2 sistem diagram blok QES

\section{Diskusi}

\subsection{Percobaan Forbes et. al}

Kami membandingkan nilai TS yang kami dapatkan dengan percobaan yang telah dilakukan sebelumnya oleh Forbes, Simmonds, dan Edward[5] yang mengukur nilai TS dari bola sphere dengan diameter yang berbeda-beda.

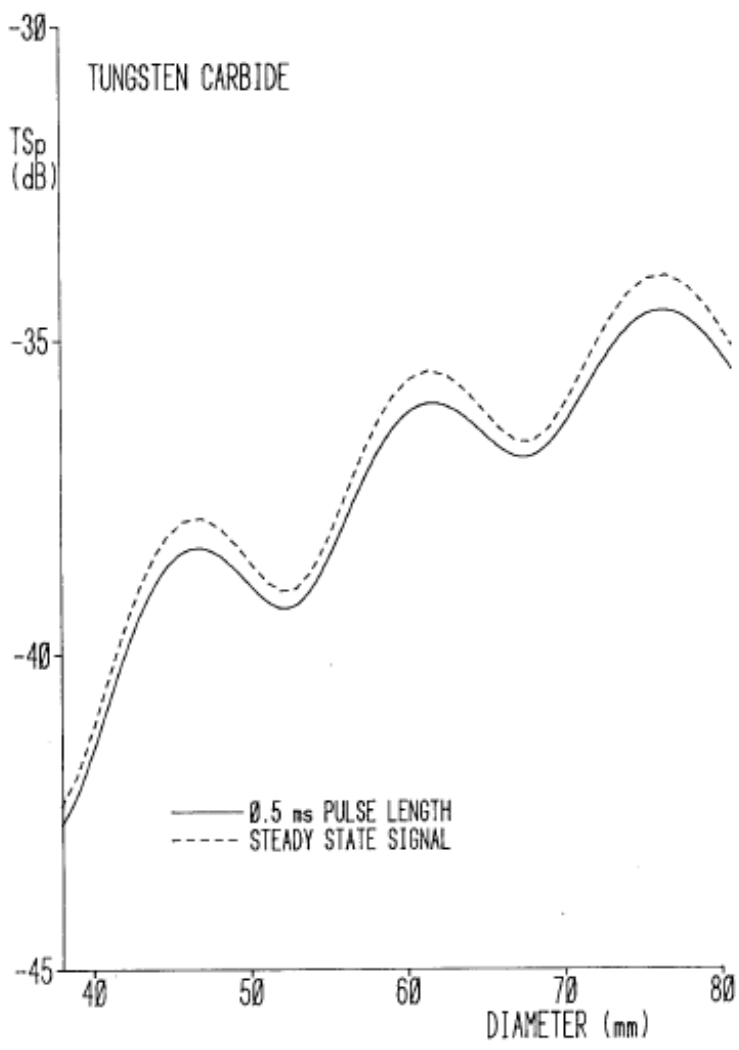

Gambar 3 target strength dari sphere tungsten carbide

Berdasarkan percobaan yang dilakukan oleh Forbes et. al tersebut, semakin besar ukuran bola sphere maka nilai TS akan semakin besar juga, namun hubungan keduanya tidak linear, melainkan pada ukuran-ukuran tertentu nilai TS akan kembali mengecil baru kemudian membesar lagi. Hasil yang didapatkan dari percobaan tersebut menunjukkan bahwa bola sphere dengan ukuran diameter $35 \mathrm{~mm}$ memiliki nilai TS di antara $-40 \mathrm{~dB}$ sampai $-45 \mathrm{~dB}$. Hasil yang kami dapatkan, yaitu TS dari bola sphere yang diukur dengan instrumen CruzPro PcFF88 memiliki nilai $-42.5 \mathrm{~dB}$ berada di dalam rentang nilai dari percobaan Forbes et. al. 


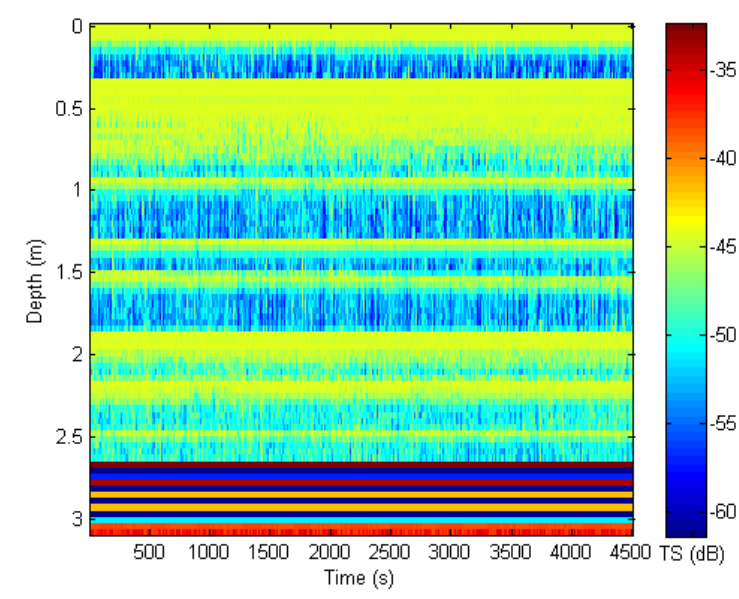

Gambar 4 echogram TS hasil rekaman CruzPro PcFF88

Gambar 4 menunjukkan hasil echogram atau nilai echo bola sphere pada kedalaman $1 \mathrm{~m}$ yang diukur menggunakan instrumen CruzPro PcFF88. Dari echogram tersebut dapat diketahui bahwa nilai TS dari bola sphere adalah $-42.5 \mathrm{~dB}$.

\subsection{Parameter SONAR}

\section{Source Level}

Source level (SL) dari proyektor ke segala arah selalu direferensikan pada jarak standar $1 \mathrm{~m}$ atau 1 yard dari pusat akustiknya (dalam hal ini adalah bola sphere). Menurut Waite[6], pada jarak $1 \mathrm{~m}$ dari pusat akustik bola sphere dengan luas area $4 \pi r^{2}$ $=12.6 \mathrm{~m}^{2}$. Jika daya luaran yang digunakan adalah $P$ watt, SL didefinisikan dengan persamaan

$S L=10 \log \left(\frac{I_{i}}{I_{r}}\right)$

$=10 \log \left(\frac{P / 12.6}{0.67 \times 10^{-18}}\right)$

$=10 \log P+10 \log \left(1.1846 \times 10^{17}\right)$

$\mathrm{SL}=10 \log P+170.8 \mathrm{~dB}$

(jika jarak standar adalah 1 yard, $\mathrm{SL}=10 \log P+$

$171.5 \mathrm{~dB}$ ). Karena $P$ yang digunakan saat pengambilan data adalah 320 Watt, maka SL = $195.85 \mathrm{~dB}$.

\section{Transmission Loss}

Transmission loss (TL) atau yang biasa sering disebut juga sebagai propagation loss (PL) adalah perhitungan kuantitatif dari hasil reduksi intensitas suara antara sumber dan target. PL dapat disebabkan oleh spreading loss maupun absorpsi dari kolom perairan. Pada kasus bola sphere, power dari transducer diradiasikan ke semua arah sama besarnya. Karena $P=$ intensitas $\times$ area,

$$
P=4 \pi r_{1}{ }^{2} I_{1}=4 \pi r_{2}{ }^{2} I_{2}=\cdots=4 \pi r^{2} I_{r}
$$

dan jika $r_{1}=1 \mathrm{~m}$, fungsi PL menjadi

$P L=10 \log \left(\frac{I_{i}}{I_{r}}\right)=10 \log r^{2}$

atau dalam bentuk logaritmik,

$P L=20 \log r$ dimana $r$ dalam meter. Jarak antara transducer dan bola sphere adalah $1 \mathrm{~m}$, maka nilai PL adalah $0 \mathrm{~dB}$.

(a)

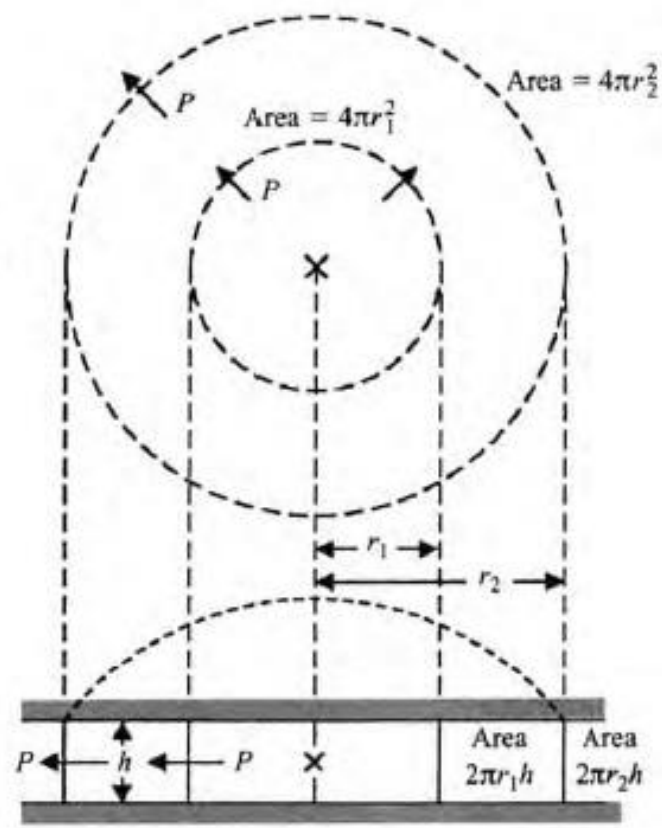

Gambar 5 spreading loss

\section{Kesimpulan}

Frekuensi $200 \mathrm{kHz}$ merupakan frekuensi yang biasanya digunakan untuk survei ikan di laut dangkal. Untuk kalibrasi instrumen dengan menggunakan target bola sphere dengan diameter sekitar $40 \mathrm{~mm}$, nilai TS yang harus dikeluarkan oleh instrumen tersebut haruslah berkisar $-42 \mathrm{~dB}$ atau lebih besar. Instrumen CruzPro PcFF88 sudah terkalibrasi dengan baik.

\section{Daftar Pustaka}

Pada teks, dafar pustaka harus disitasi dengan menuliskan no urut daftar pustaka

Contoh penulisan daftar pustaka :

[1] K.G. Foote, "Optimizing copper spheres for precision calibration of hydroacoustic equipment," J. Acoust. Soc. Am. 71, 742-747 (1982).

[2] K.G. Foote, H.P. Knudsen, G. Vestnes, D.N. MacLennan, and E.J. Simmonds, "Calibration of Acoustic Instruments for Fish Density Estimation: A Practical Guide," International Council for the Exploration of the Sea (1987).

[3] K. Sawada and M. Furusawa, "Precision calibration of echo sounder by integration of standard sphere echoes," J. Acoust. Soc. Jpn. (E)14, 4 (1993) 
[4] D. N. MacLennan, "The Theory of Solid Spheres as Sonar Calibratlcm Targets," Scottish Fisheries Research Report (1981).

[5] S.T. Forbes, E.J. Simmonds, and J.I. Edwards, "Progress in target strength measurements on live gadoids. Marine Laboratory Working Paper No. 80/15, 40 pp. (mimeo) (1980).

[6] A.D. Waite, "SONAR for Practising Engineers. UD, England: John Wiley \& Sons, Ltd (2002). 